\title{
THE WEBER-FECHNER LAW AND PUBLIC EXPENDITURES IMPACT TO THE WIN-MARGINS AT PARLIAMENTARY ELECTIONS
}

\author{
Paulo Jorge Reis Mourao*
}

\begin{abstract}
:
This paper discusses the electoral implications of psychological motivation on voting functions. We tested a claim of the Weber-Fechner law as applied to electoral behaviour-specifically, that an expanded public sector leads politicians to make more significant, opportunistic distortions of public expenditures than the distortions observed when the public sector is diminished. We employed a system of simultaneous equations to test this hypothesis for cases observed in more than sixty democracies since 1960 . We gave a special focus to the cases of Central and Eastern European countries. Our results confirm the main implications of the Weber-Fechner law. Years in incumbency, running for re-election, higher unemployment and higher inflation rates tend to generate negative moods, feelings and affects in the electorate; thus, these factors tend to approximate the vote share of the most voted party to the remaining vote share of the challenger political forces.
\end{abstract}

Keywords: voting, Central and Eastern European economies, Weber-Fechner law

JEL Classification: D72, P20, D03

\section{Introduction}

Economic models tend to present public agents as agents who try to stimulate the economy using various instruments. Actually, stimulating the economy is a figure of speech, namely, a personification. In fact, public agents, e.g., political office seekers or incumbents, try to stimulate the behaviour of electors and constituents to improve economic performance, perhaps, but also to gain the prestige that will ultimately prolong their political tenure.

In pursuing this goal, incumbent politicians need to be heard by voters, a task which itself involves being well understood while minimizing noise, interference and distortions of their political message. This messaging is crucial for politicians who want to maximize votes.

Politicians' messages, ideas and contributions to public discourse face many possible interfering elements that can make it difficult to be sure that the desired message is correctly received by the recipients.

* Economics \& Management School, University of Minho, 4700 Braga - Portugal (paulom@eeg. uminho.pt). The author acknowledges the valuable suggestion of two anonymous referees on a previous version of this paper. Remaining limitations are author's exclusive ones. 
Additionally, politicians seek to maximize the effect of political instruments on the perceptions of potential voters. In other words, politicians want to optimize the perceived quality of their messages and actions.

Specially, this need for generating messages that will capitalize on popularity is more intense in the run up to elections. In these periods, opportunistic actions on the part of office seekers are more frequent, and emotional reactions in the electorate can have a more dramatic effect on voting. In this work, we test how emotional reactions motivated by specific socio-economic dimensions can lead to changes in electoral behaviour.

From psychological studies, we know that the perception of a stimulus (here, a political stimulus) depends on the environment around the perceiving agents. This leads us to discuss the Weber-Fechner law.

Recall that according to this law, the marginal perception reacts to the marginal increase of the stimulus divided by the initial amount of that stimulus. Building on our previous claims and focusing specifically on economic and political actions, this law suggests that large budgets would tend to diminish the impact of revenues and expenditures in the electorate's perspective, unless unusual significant changes in budget aggregates are observed. Our study, then, aims to test the validity of this Weber-Fechner claim using electoral data.

We believe this procedure will be a novel approach in economic and electoral research. There are some works on pricing and testing the utility of money that apply the WeberFechner law, but none of them have tested it using economic and electoral data.

The remainder of the paper is structured as follows. Section 2 discusses how economic dimensions motivate different feelings and affects in the electorate. The section also addresses the Weber-Fechner law as a tool for explaining why opportunist distortions (i.e., politically-motivated increases of expenditures) may be larger when the public sector enlarges, too. Section 3 introduces our system of simultaneous equations and the data we tested. Section 4 discusses our results, and Section 5 offers the conclusions from our research.

\section{Economic Factors, Psychological Reactions and Electoral Consequences - a Review of Literature}

\subsection{From political stimuli in the economy to the Weber-Fechner law}

Edelman (2001) and Caplan (2007) suggest that, in periods of competitive polls, politicians take advantage of some particular stimuli on voters' behaviour, e.g., enthusiastic discourses or budget changes (Puviani, 1903, called these instruments political illusions). For these authors, illusions aim to strengthen the effects on voters of benefits gained from opportunistic expenditures and less taxation. Opportunistic messages (highlighting an exaggeratedly positive image of the incumbents' actions) 
are also used as a counter-instrument to the exacerbated negative image of incumbents' actions promoted by opposing politicians.

Authors focusing on rational political business cycle models like Nordhaus (1975), Tufte (1978), Hibbs $(1977,1987)$ and, more recently, Shi and Svensson (2006) have also studied opportunistic distortions of other political instruments-namely, budget aggregates. These studies suggest that shortly before elections, politicians tend to engage in opportunistic practices like exhibiting more public expenditures than their trend values or alleviating taxation, which results in less public revenue. The reasons for this behaviour are heterogeneous, and the explanation given depends on the generation of the author. For instance, Nordhaus (1975) emphasized the signalling of competences, whereas Hibbs (1987) stated that politicians try not to disappoint groups of electors who usually vote for these politicians. More recently, Shi and Svensson (2002) and Alt and Lassen (2006) suggest that politicians not only engage in opportunism as a strategy in their agenda but also because they intend to generate information asymmetry on public issues. Edelman (2001) discusses the ways in which this information asymmetry is supported by many sources of political illusion.

We can consider these actions and these messages from incumbents as stimuli on voters' behaviour. This interpretation concurs with Kates (2004) and Lewis-Beck et al. (2008).

We follow Coates (2004), Shoemaker and Reese (1991) and Conover (1981) to model the tactics of incumbents intending to be re-elected. The expected win-margin can be identified as $k$. Therefore, incumbents want to maximize the perception (p) of their instruments $(\mathrm{G})$ by electors weighted by $k$. $\mathrm{p}$ is a convex function like $\mathrm{p}=\mathrm{k} * \ln (\mathrm{G})$.

Accordingly, the Objective-function for the incumbent is $\operatorname{Max} p=k^{*} \ln (G)$.

Our first order conditions are

$$
d p / d G=k / G .
$$

Re-arranging this, we arrive at the Weber-Fechner law:

$$
d p=k^{*}(d G / G) .
$$

Bellany (1973) comments that "the Weber-Fechner law states the psychological sensation produced by a physical stimulus is proportional to the logarithm of that stimulus." According to Zafirovski (2001), "any change in our level of sense perception is closely and proportionally related to any change in the intensity of the stimuli that were just acting on the senses."

One implication of this first order condition is that for the difference between magnitudes $(\mathrm{dG})$ to be perceived (dp), the difference must be larger for larger magnitudes $(\mathrm{G})$, because otherwise dp converges to zero. Figure 1 shows this. 
Figure 1

The Weber-Fechner Law Illustrated [case $\left.p=2^{\star} \ln (G)\right]$

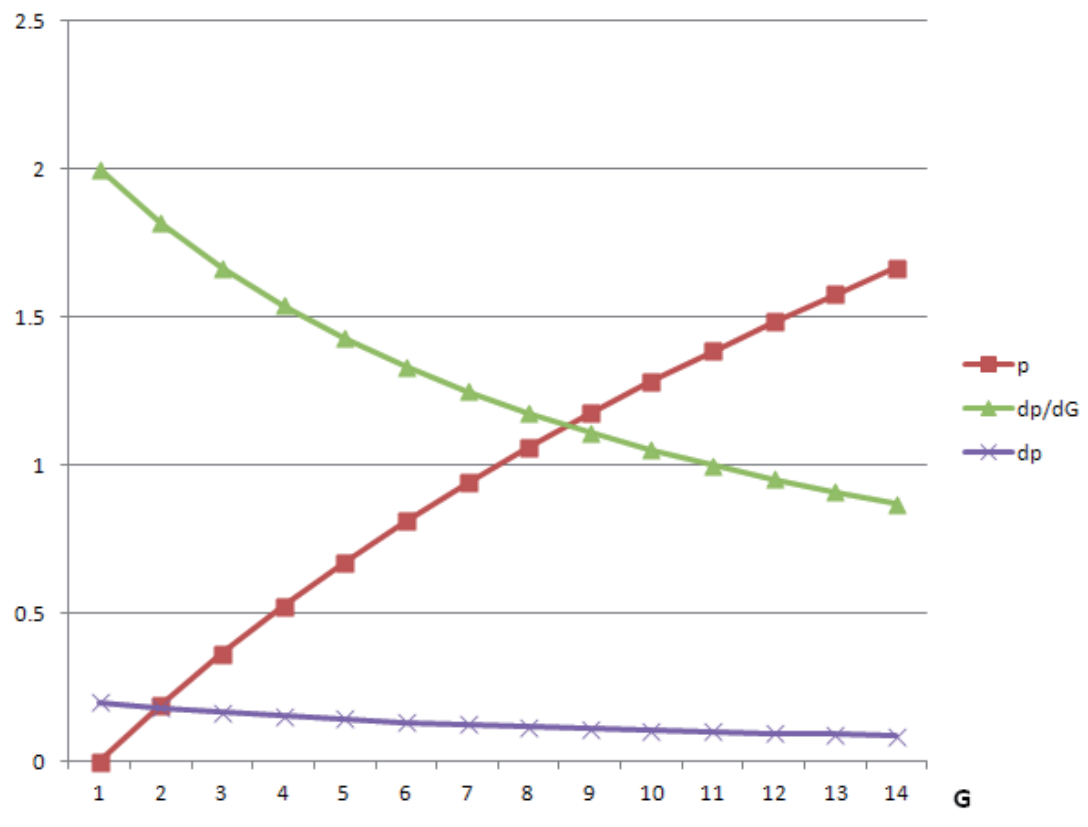

Consider the case of public expenditures as the stimulus on voters. Here, incumbent politicians need to show higher and higher expenditures to get a positive reaction from voters. When a politician seeks to influence an outcome of an election by a fiscal stimulus, the impact of the increase in spending depends on how much the government was spending with. Voters do not perceive the increment of smaller differences and will not favour the politicians at the polls. Therefore, these conclusions derived from studying the Weber-Fechner law ${ }^{1}$ can be realized as additional explanation for the growth of public expenditures, until now hardly explored by the literature.

Recent investigations (Aidt, Veiga and Veiga, 2010) have also found that the perception of political stimuli (dp) may also be influenced by factors other than the size of the public sector. Some of these factors are the expected win-margin at the polls, whether or not an incumbent is running for re-election, the political wing of the most voted parties ("left" or "right" wings) and the proportion of the population that has completed secondary school.

Thus, it is appropriate to re-write the conventional Weber-Fechner law as

$$
d p=f(d G / G ; M V E ; y 1 ; y 2 ; y 3)
$$

1 For a larger discussion of the Weber-Fechner law, since its origin until its expansion over different scientific domains, we suggest Weber (1834), Fechner (1860), Mises (1949), Stevens (1962, 1975), Sinn (2003), Skouras et al. (2005), or Masin et al. (2009). 
According to Equation 1, political stimuli (dp) generated by incumbent politicians depend on the intensity of political instruments $(\mathrm{dG} / \mathrm{G})$, on the expected win-margin (MVE), on running for re-election (y1), on political wing (y2) and on the proportion of population having completed secondary school (y3). However, there is a vast economic and political literature discussing the determinants of the expected win-margins. Next sub-section discusses it.

\subsection{Electoral win-margins as a function of economic and non-economic factors}

Electoral behaviour is the consequence of perceptions on the economic reality but it is also a product of non-economic factors. For instance, authors who subscribe to the theory of affective intelligence (Marcus, Neuman and MacKuen, 2000) claim that politicians try to manipulate affects, emotions and feelings of electors close to the election time.

Brader (2005) has developed this theme:

"Emotions are specific sets of physiological and mental dispositions triggered by the brain in response to the perceived significance of a situation or object for an individual's goals... [whereas] feelings are the subjective awareness and experience of emotions... where emotions are discrete responses to specific stimuli, moods are diffuse positive or negative states that last for longer periods of time... affect is an umbrella term referring to an entire class of phenomena that is often taken to include not only emotions, feelings, and moods, but also pain, pleasure, and basic human drives." (Brader, 2005, p. 51; emphasis in original)

Incumbents try to manipulate affects when they run for re-election. As an affect is a structural construction, it is based on the experience accumulated between each elector and each incumbent. The incumbent tries to use affective resources to reduce the erosion of popularity likely to accompany his or her incumbency. The same effect happens via the identification of each voter with a particular political force or with a particular party. Consequently, some politicians prefer to run allied with other politicians from alternative parties to attract the most voters.

With regard to the effect of a candidate's years in incumbency, Stimson (1999) suggests that moods are operating in electoral behaviour. Recall that moods are "diffuse images that last for long periods of time" (Brader, 2005). Just as prestigious images associated with an incumbent counter the eroding effect of time on popularity, a weak reputation gained by a politician generates persistent moods that will accelerate the erosion of his or of her popularity.

Emotions are specific dispositions. These dispositions change due to egotropic (Kinder and Kiewiet, 1981; Kramer, 1983) and to sociotropic (Marcus, 1988) feelings that are exacerbated by some motivations. The most cited motivations in the relevant literature are one's status of employment/unemployment and the perception of inflation (Nannestad and Paldam, 1994). Usually, these motivations erode the prestige of incumbents and tend to close the gap between the two most popular parties. 
At this point, we can define that vote functions and (concomitantly) win-margin functions depend on the dimensions that we have described as related to affects, moods, emotions and feelings in electoral behaviour: the previous values of the win-margins, the candidate's years in incumbency, whether or not the candidate is running for re-election, the unemployment rate, the inflation rate, the number of parties in government, and the political stimuli that incumbents can bring to bear on the economy (for instance, fiscal stimuli like positive changes in expenditures).

We can formulate this claim as our Equation 2:

$$
M V E_{t}=f\left(M V E_{t-1} ; x 1 ; x 2 ; x 3 ; x 4 ; x 5 ; G\right)
$$

In our Equation 2, MVE means win-margin of the most voted party relative to the second most voted party. This win-margin is observed at the moment $t$, and it is conditioned by the previous win-margin, years in incumbency (x1), running for re-election $(\mathrm{x} 2)$, the unemployment rate $(\mathrm{x} 3)$, the inflation rate $(\mathrm{x} 4)$, the government fractionalization $(\mathrm{x} 5)$ and the set of political stimuli in the form of fiscal instruments $(\mathrm{G})$.

The rest of this paper is devoted to empirically testing our Equations 1 and 2.

We will focus our analysis on the 68 democracies previously analyzed by Brender and Drazen (2004), ${ }^{2}$ and we will especially consider the cases of ten Central and Eastern European (transition) democracies ${ }^{3}$.

These Central and Eastern European democracies are young democracies, with less than 20 years, on average, of democratic experience. Most of these countries were ruled by dictatorial regimes up until the last two decades. A key motivation for focusing on these countries is found in the many articles-such as Shi and Svensson (2006) or Alt and Lassen (2006) — that show that win-margins and the perception of political messages by electors depend on the democratic experience of the electorate as a whole. Therefore, countries with established democratic regimes exhibit different electoral and political behaviours than countries characterized by young democracies. Finally, these Central and Eastern European cases may pick up specific influences on the behaviour of electors from sharing not only borders but also many idiosyncratic and cultural characteristics with western European countries. This fact may produce different results from those estimated for other young democracies (such as Latin American democracies or East Asian democracies).

\footnotetext{
2 Argentina, Australia, Austria, Belgium, Bolivia, Brazil, Bulgaria, Canada, Chile, Colombia, Costa Rica, Cyprus, the Czech Republic, Denmark, Dominican, Ecuador, El Salvador, Estonia, Fiji, Finland, France, Germany, Greece, Guatemala, Honduras, Hungary, Iceland, India, Ireland, Israel, Italy, Japan, Korea, Lithuania, Luxembourg, Madagascar, Malaysia, Mali, Mauritius, Mexico, Nepal, Netherlands, New Zealand, Nicaragua, Norway, Pakistan, Panama, Papua, Paraguay, Peru, Philippines, Poland, Portugal, Romania, Russia, Slovakia, Slovenia, South Africa, Spain, Sri Lanka, Sweden, Switzerland, Trinidad, Turkey, the United Kingdom, the United States Of America, Uruguay and Venezuela.

3 Bulgaria, the Czech Republic, Estonia, Hungary, Lithuania, Poland, Romania, Russia, Slovakia and Slovenia
} 


\section{Data and Empirical Specifications}

As has been stated, we tested our hypotheses with a system of two simultaneous equations.

The first equation (3) uses as a dependent variable a measure of win-margin (MVE) recorded in legislative elections. Our measure for win-margin, suggested by Aidt et al. (2010), is equivalent to the difference in vote shares between the party with the most votes and that with the second most.

The second equation (4) describes political stimuli from public expenditures (OE) observed in an election year. Calculation of this deviation also follows Aidt et al. (2010). It is equivalent to the percentage deviation of public expenditures as shares of GDP in an election year from the legislative election term average.

Our system of two simultaneous equations has the following form:

$$
\begin{aligned}
& M V E_{i t}=\beta_{1} G_{i t}+\sum_{j=2}^{m} \beta_{j} X_{i t}+v_{i}+\delta_{t}+\varepsilon_{i t} \\
& G_{i t}=\chi_{1} M V E_{i t}+\sum_{j=2}^{n} \chi_{j} Y_{i t}+\tau_{i}+\vartheta_{t}+\mu_{i t}
\end{aligned}
$$

In this system, $i=1, \ldots, 68$ identifies each of the 68 democracies observed by Brender and Drazen (2004), which we have upgraded, and $t$ indexes each legislative election year between 1960 and 2006. Both equations include country-fixed effects $\left(v_{1}\right.$ and $\left.\tau_{1}\right)$ and time-fixed effects $\left(\delta_{t}\right.$ and $\left.\vartheta_{t}\right)$. Random errors $\left(\varepsilon_{i t}\right.$ and $\left.\mu_{i t}\right)$ are expected to be null.

Column X comprises variables that influence vote functions, including win-margin from the previous election, years in office of the most voted party, a dummy for re-election, unemployment rate, inflation rate, fractionalization of the government and a dummy for Central and Eastern European countries.

Column Y comprises variables that influence political stimuli on the economy, including term average values for public expenditures as shares of GDP, years in office of the most voted party, a dummy for re-election, a dummy for right-wing party (in incumbency), the proportion of people to have completed secondary education and a dummy for Central and Eastern European countries.

The following parameters are then estimated: $m \beta$ 's related to the $\mathrm{X}$ column and $n \chi$ 's related to the $\mathrm{Y}$ column.

The literature suggests that $\beta_{1}>0$ and $\chi_{1}<0$ for public expenditures. In this case, the literature also suggests positive distortions of public expenditures in an election year and that higher expected win-margins reduce these distortions.

Related to the remaining $m-1 \beta_{j}$, we expect the following. Years in office of the most voted party, running for re-election, unemployment rate and inflation rate are characterized by negative $\beta_{j}$. These negative $\beta_{j}$ mean that an increase in the values 
of these variables reduces the win-margins of the most voted parties. According to Aidt et al. (2010), the $\beta_{j}$ of the previous win-margin should be positive. Government fractionalization and the condition of being a Central or a Eastern European country are also characterized by positive $\beta_{j}$.

We also expect the $\chi_{j}$ to have the following signals: average term values for shares of public expenditures in GDP should produce a positive effect on our measure of distortion. According to the Weber-Fechner law, distortions in expenditures are larger if the share of public expenditures in GDP is also larger. Larger expected win-margins, the case of running for re-election and higher shares of population with secondary school completed shall reduce our dependent variable in Equation 2.

Chote et al. (2008) showed that the greater number of years in office provides incumbents with special knowledge. Being more aware of national public finances, incumbents tend to increase taxation and tend to reduce public expenditures-particularly when running for re-election-in order to signal competence.

Brug et al. (2007) and Aidt et al. (2010) suggest that for right-wing parties, the coefficient $\chi_{j}$ can be negative. On this theme, it is noteworthy that few studies clearly indicate the effect of a party's identification as left or right-wing on its candidates' tendencies toward political opportunism. Consequently, we will not give a definitive sign for this variable (although Aidt et al. (2010) found that right-wing Portuguese mayors showed fewer opportunistic practices while Brug et al. (2007) argue that left-wing governments tend to reduce unemployment through more opportunistic policies than right-wing governments more concerned with targeting inflation).

The presence of a more educated population may reduce these effects. We thus expect the condition of having a higher percentage of population to have completed secondary education to reduce the positive deviations in public expenditures. This expectation agrees with the findings of Caplan (2007), who argued that more educated electors are less reactive to opportunistic practices.

The maturity of institutions reduces these opportunistic distortions. Therefore, the $\chi_{j}$ of the dummy variable related to a country belonging to Central and Eastern Europe shall be positive for distortions of public expenditures.

\section{Data}

For measuring win-margin, we followed Aidt et al. (2010), and our win-margin is also equivalent to the difference between the vote shares of the two dominant parties in legislative elections in 68 countries since $1960 .^{4}$

$4 \quad$ We ran alternative estimations of our systems of simultaneous equations using Niskanen (1998) as another measure for the win-margin. The measure suggested by Niskanen (1998) is equivalent to the (log) ratio between the vote share of the most voted party and the sum of the vote shares of all the other parties. The signals and the significance level of the estimated coefficients obtained with Niskanen (1998) evidence the same direction and the same significance levels of the estimated coefficients here reported. However, results with Niskanen (1998) measure are available upon request. 
Our measures of distortion in budget aggregates have also been influenced by the measures of Aidt et al. (2010). As a measure of political stimuli via public expenditures, we used percentage deviation in shares of public expenditures in GDP from the election term average.

The main sources of our database were Database of Political Institutions (2008), International Financial Statistics (2006) and Brender and Drazen (2004).

The Database of Political Institutions (2008) provided data for construction of the win-margin variable and years in office of the most voted party, identification of a case of a party running for re-election, fractionalization of the government and political wing identification of the of the most voted party.

International Financial Statistics (2006) provided data on inflation rates and unemployment rates.

We updated Brender and Drazen's (2004) database with the most recent values of variables related to shares of public revenue and public expenditures in GDP. For our measures of the percentage of the population with secondary education, we used Barro and Lee (2000) updated with values from World Bank databases.

Table 1 shows the descriptive statistics of the variables.

\section{Results}

The first column in Table 2 shows estimations of Equations 1 and 2 by the generalized method of moments (GMM). Table 2 summarizes the relationship between win-margin and public expenditure opportunism. Standard errors are shown in parentheses. Adjusted R2 and numbers of observations are also reported in Table 2.

We verify that the results validate the main implications of the Weber-Fechner law because distortions in public expenditures are significantly influenced by the average size of public expenditures. A $1 \%$ increase of the term average public expenditures as a share of GDP leads to an increase of $0.056 \%$ in our measure of political stimuli. As the public expenditures increase in size, incumbents need higher deviations in budget aggregates to stimulate the economy.

We also verify that a $1 \%$ increase in public expenditures over a term average generates an increase of $2.6 \%$ in expected win-margin. ${ }^{5}$

The other results from column 1 in Table 2 correspond to our previous expectations. Years in incumbency, running for re-election, higher unemployment and higher inflation rates tend to generate negative moods, feelings and affects in the electorate, which ultimately equalize the vote share of the most voted party with the remaining combined vote share of the opposing political forces. A higher number of parties associated in

5 Confirm the estimates for the variable distortion in expenditures as a regressor for win-margins (Table 2). 
government and higher win-margins from the previous election increase our measure of win-margin via the effects of affect, as has been noted. The dummy for Central and Eastern European countries received a positive estimated coefficient (0.062). This estimate shows that the legislative elections recorded in Central and Eastern European countries in our sample tend to be characterized by higher differences between the vote share of the most voted party and the remaining vote share than the differences observed in the other democracies.

Deviations in public expenditures (Table 2, lower panel) tend to be increased when the size of the public sector is larger (measured as the share of public expenditures in GDP), corroborating the Weber-Fechner law. Recall that according to this law, the marginal perception reacts to the marginal increase of the stimulus divided by the initial amount of that stimulus. Thus, as the size of public sector increases, politicians tend to need higher (positive) deviations in public expenditures to gain the same attention from the electorate.

These deviations in public expenditures also tend to be increased in Central and Eastern European countries, where democratic institutions are younger (Alt and Lassen, 2006; Brender and Drazen, 2006; Akhmedov and Zhuravskaya, 2004).

Deviations in public expenditures tend to be diminished when a more educated electorate is more expressive, when incumbents have higher expected win-margins and when incumbents run for re-election. In these cases, the political distortion is more controlled. We can interpret these cases in two primary ways. First, more educated electors know that higher expenditures today mean higher taxes tomorrow, and such electors tend to show more immunity to these opportunistic actions. Second, being more aware of voters, incumbents try to diversify their range of instruments to include those beyond the normal fiscal ones (which lead a smaller room to distortions in expenditures as efficient actions).

We also produced estimates for the system of simultaneous equations by two other methods: three stages least squares (3SLS) and full information maximum likelihood (FIML). Results with these methods are reported in columns 2 and 3 of Table 2. These results are not significantly different from results obtained with GMM. ${ }^{6}$

Based on the statistical significance of the coefficients estimated for the dummy for Central and Eastern European countries observed in Table 2, we followed authors like Brender and Drazen (2007) and Alt and Lassen (2006), who suggest splitting the samples according to the maturity level of democracies. This procedure clarifies the differences in the coefficients to be estimated, avoiding the too restrictive assumption of homogeneous coefficients when the sample is not divided.

Tables 3 and 4 show the estimates in our system of simultaneous equations with countries split into Central and Eastern European countries and non-Central and Eastern European

6 We also have estimated the remaining systems of equations by 3SLS and FIML although we only report here the (robust) GMM estimations for parsimony. 
countries. Generically, results from Tables 3 and 4 agree with results in Table 2. We verified again that previous significant win-margins, government fractionalization and positive distortion in expenditures tend to promote higher win-margins in all cases. Conversely, more years in incumbency, running for re-election, higher unemployment rates and higher inflation rates tend to promote smaller win-margins.

We additionally verified that higher win-margins decrease opportunist distortions in public expenditures (leading to a negative effect on public outlays).

We also tested the overall significance of time dummies for Central and Eastern European countries. We got results that did not lead us to reject the null hypothesis of non-significance of the coefficients estimated for these time variables. We interpret this fact by the absence of a time trend influencing per se the transition process more focused on the dynamics of political and economic cycles.

Results with 3SLS and FIML from the system of simultaneous equations divided into Central and Eastern European countries and non-Central and Eastern European countries are available from the authors upon request. Indeed, the GMM estimator is more robust than FIML because GMM does not require additional information related to disturbances; GMM is based on the assumption that disturbances in the equations are not correlated with the set of instrumental variables. With a weighting matrix used in the criterion function, GMM is even more robust than 3SLS in heteroskedasticity and autocorrelation of unknown form (Wooldridge, 2002; Hsiao, 2002).

These results, however, depend on the level of maturity of institutions, signalled by a country being a Central or Eastern European country (or not).

For Central and Eastern European countries, the weight of being young democracies has a clear impact in our results. Previous win-margins and government fractionalization lead to higher effects than for non-Central and Eastern European countries. Running for re-election is also less erosive for an incumbent in a Central or in Eastern European democracy than in the rest of our sample. There is a statistically significant difference estimated for the impact of higher inflation rates: for Central and Eastern European countries, a higher inflation rate leads to a smaller deterioration in win-margins. We also observed that for Central and Eastern European countries the claims of the Weber-Fechner law are more evident: as the public sector increases in size, so do the distortions in expenditures that politicians need to signal competency.

Some political implications derive from these results. First of all, they prove that WeberFechner principles can be a powerful explanation for the debate around the increasing trend of public expenditures that economies observe during some periods, namely because of the need of more intense public expenditures for a higher perception by voters. Secondly, we proved that political results are not only the product of economic circumstances but they are also the product of a complex relationship between politicians and their electorates, where affections and moods and other psychological dimensions may be as relevant as the traditional economic ones. Finally, we concluded that our estimates for Central and Eastern European countries demonstrate that their 
electorates are more reactive to positive distortions in public expenditures than electorates from other countries (namely OECD countries); this reaction can help on explaining the larger win-margins observed in electoral polls in Central and Eastern European countries when contrasted to other countries.

\section{Conclusion}

Voting is a response to specific stimuli (constitutional, psychological or economic stimuli). This work tested how specific economic stimuli interfere with electoral results. Specifically, we focused on two main electoral objects: win-margins and opportunistic distortions.

Various authors have claimed that voting changes due to particular feelings, moods or affections. We have observed that these feelings, moods and affections change because of incumbency length, inflation and unemployment rates or because of the previous win-margins observed in the previous electoral race. In a different body of work, economists and political scientists claim that the old Weber-Fechner law can be observed in the current political behaviour: as the public sector enlarges, political agents have to exhibit increasingly significant signals of competence to be positively evaluated by their co-citizens.

We wanted to empirically test these claims using a sample of more than sixty democracies, highlighting the Central and Eastern European countries. All of the countries featured in the study have been observed since 1960 .

Our results confirm the main implications of the Weber-Fechner law because distortions in public expenditures are indeed significantly increased by the average size of public expenditures.

We also verify that an increase in public expenditures over a term average generates an increase in expected win-margin.

Years in incumbency, running for re-election, higher unemployment and higher inflation rates tend to generate negative moods, feelings and affects in the electorate that lastly approximate the vote share of the most voted party to the remaining vote share of the challenger political forces.

The deviations in public expenditures also tend to be larger in Central and Eastern European countries, where democratic institutions are still under a process of consolidation.

We believe this work contributes interesting results to the literature. Our results have further shown that the Weber-Fechner law holds for our sample and that win-margins can be explained by particular stimuli promoted by the social and economic moment.

The main implication of our results is to warn that as the public sector enlarges, there are increasing incentives for greater opportunism because politicians need to signal competences by robust strategies, specifically a more visible use of public expenditures. 
With regard to Central and Eastern European countries widely recognized as young democracies, our findings suggest that it is also important that control of political opportunism be exercised because these relatively "young" electorates tend to be more reactive to social and economic instability.

\section{References}

Aidt, T., Veiga, F., Veiga, L. (2010), "Election Results and Opportunistic Policies: A New Test of the Rational Political Business Cycle Model." Public Choice. Forthcoming. DOI 10.1007/ s11127-010-9644-3.

Akhmedov, A., Zhuravskaya, E. (2004), "Opportunistic Political Cycles: Test in a Young Democracy Setting." The Quarterly Journal of Economics 119, No. 4, pp. 1301-38.

Alt, J., Lassen, D. (2006), "Fiscal Transparency, Political Parties, and Debt In OECD Countries." European Economic Review 50, No. 6, pp. 1403-39.

Barro, R., Lee, J. (2000), "International Data on Educational Attainment: Updates and Implications." Manuscript, Harvard University.

Bellany, I. (1973), "The Problems of Balancing Reductions in Conventional Forces." The Journal of Conflict Resolution, Vol. 17, No. 4 (Dec. 1973), pp. 657-671.

Bernoulli, D. (1738), Specimen theoriae novae de mensura sortis. Commentarii Academiae Scientiarum Imperialis Petropolitanae. 5. Ed., pp. 175-192.

Brader, T. (2006), Campaigning for Hearts and Minds: How Emotional Appeals in Political Ads Work. Chicago: The University of Chicago Press.

Brandstätter, E., Brandstätter, H. (1996), "What's Money Worth? Determinants of the Subjective Value of Money." Journal of Economic Psychology. Vol. 17, pp. 443-464

Brender, A., Drazen, A. (2004), "Political Budget Cycles in New versus Established Democracies." NBER Working Papers Series 10539, 2004. (http://www.econ.umd.edu/ drazen/Data_Sets/ Data_Sets.html).

Brender, A., Drazen, A. (2007), "Electoral Fiscal Policy in New, Old, and Fragile Democracies." Comparative Economic Studies Vol. 49, No. 3, pp. 446-66.

Brug, W., C. Eijk, Franklin, M. (2007), The Economy and the Vote: Economic Conditions and Elections in Fifteen Countries. Cambridge: Cambridge University Press, 2007.

Caplan, B. (2007), The Myth of the Rational Voter. Princeton: Princeton University Press, 2007.

Chote, R., C. Emmerson, Tetlow, G. (2008), "The UK Public Finances: Ready for Recession?" The Institute for Fiscal Studies, IFS Briefing Note 79 (2008).

Coates, D. (2004), "Additional Incumbent Spending Really Can Harm (at least some) Incumbents: An Analysis of Vote Share Maximization”. Public Choice Vol. 95, pp. 63-87.

Conover, P. (1981), "Political Cues and the Perception of Candidates". American Politics Quarterly, Vol. 9, pp. 427-448.

DPI (2008), Database of Political Institutions. Washington, DC: World Bank, 2008.

Edelman, M. (2001), The Politics of Misinformation: Communication, Society and Politics. Cambridge: Cambridge University Press, 2001.

Fechner, G. (1860), Elemente der Psychophysik. Lepzig: Breitkopf und Härtel, (reprint Amsterdam: Bonset, 1964).

Hibbs, D. (1977), "Political Parties and Macroeconomic Policy." American Political Science Review, Vol. 71, pp. 1467-87.

Hibbs, D. (1987), The American Political Economy: Macroeconomics and Electoral Politics. Cambridge: Harvard University Press, 1987.

Hsiao, C. (2002), Analysis of Panel Data. Cambridge: Cambridge University Press, 2002. 
IFS (2006), International Financial Statistics. New York: International Monetary Fund, 2006.

Kates, S. (2004), "A Qualitative Exploration into Voters' Ethical Perceptions of Political Advertising: Discourse, Disinformation, and Moral Boundaries" Journal of Business Ethics, Vol. 17, pp. 1871-85.

Kinder, D., Kiewiet, D. (1981), "Sociotropic Politics: The American Case." British Journal of Political Science, Vol. 11, pp. 129-61.

Kramer, G. (1983), "The Ecological Fallacy Revisited: Aggregate Versus Individual-level Findings on Economics and Elections, and Sociotropic Voting." American Political Science Review, Vol. 77, pp. 92-111.

Lewis-Beck, M., Norpoth, H., Weisberg, H., Jacoby, W. (2008), The American Voter Revisited. Ann Arbor: The University of Michigan Press, 2008.

Marcus, G. (1988), "The Structure of Emotional Response: 1984 Presidential Candidates." American Political Science Review, Vol. 82. pp. 737-62.

Marcus, G., Neuman, R., MacKuen, M. (2000), Affective Intelligence and Political Judgement. Chicago: The University of Chicago Press, 2000.

Masin, S., Zudini, V., Antonelli, M. (2009), "Early Alternative Derivations of Fechner's Law". Journal of the History of the Behavioral Sciences, Vol. 45, No. 1, pp. 56-65.

Nannestad, P., Paldam, M. (1994),"The VP-Function: A Survey of the Literature on Vote and Popularity Functions after 25 Years." Public Choice, Vol. 79, No. 3-4, pp. 213-45.

Niskanen, W. (1998), "A Vote for Perot Was a Vote for the Status Quo." Cato Journal, Vol. 18, No. 1, pp. 85-91.

Nordhaus, W. (1975), "The Political Business Cycle." Review of Economic Studies, Vol. 42, pp. 169-90.

Puviani, A. (1903), Teoria della illusione finanziaria, Palermo: Sandron, 1903.

Shi, M., Svensson, J. (2006), "Political Budget Cycles: Do They Differ across Countries and Why?" Journal of Public Economics, Vol. 90, pp.1367-89.

Shi, M., Svensson, J. (2002), "Political Budget Cycles in Developed and Developing Countries." Manuscript, Institute for International Economic Studies, Stockholm University, 2002.

Shoemaker, P., Reese, S. (1991), Mediating the Message. Theories of Influence on Mass Media Contents. New York, London: Longman, 1991.

Sinn, H. (2003), "Weber's Law and the Biological Evolution of Risk Preferences: The Selective Dominance of the Logarithmic Utility Function, 2002 Geneva Risk Lecture." The GENEVA Papers on Risk and Insurance - Theory; Vol. 28, No. 2, pp. 87-100.

Skouras, T., Avlonitis, G., Indounas, K. (2005), "Economics and Marketing on Pricing: How and Why Do They Differ?" Journal of Product \& Brand Management, Vol. 14, No. 6, pp. 362-374.

Stevens, S. (1962). "The Surprising Simplicity of Sensory Metrics," American Psychologist, Vol 17, No. 1, pp. 17, 29-39.

Stevens, S. (1975), Psychophysics: Introduction to its Perceptual, Neural and Social Prospects. New York: Wiley, 1975.

Stimson, J. (1999), Public Opinion in America: Moods, Cycles, and Swings. Boulder: Westview Press, 1999.

Tufte, E. (1978), Political Control of the Economy. Princeton: Princeton University Press, 1978.

Von Mises, M. (1949), Human Action: A Treatise on Economics. New Haven: Yale University Press, 1949.

Weber, E. (1834), De pulsu, resorptione, auditu et tactu. Annotationes anatomicae et physiologicae. Leipzig: Koehler, 1834.

Wooldridge, J. (200), Econometric Analysis of Cross Section and Panel Data. Cambridge, MA: MIT Press, 2002.

Zafirovski, M. (2001), "Max Weber's Analysis of Marginal Utility Theory and Psychology Revisited: Latent Propositions in Economic Sociology and the Sociology of Economics." History of Political Economy, Vol. 33, No. 3; pp. 437-458. 
Table 1

\section{Descriptive Statistics}

\begin{tabular}{|c|c|c|c|c|c|c|c|c|c|c|c|}
\hline & & $\begin{array}{l}\text { Win-margin, } \\
\text { percentual } \\
\text { points (log) }\end{array}$ & $\begin{array}{l}\text { Years in } \\
\text { Incumbency } \\
\text { of the most } \\
\text { voted party }\end{array}$ & $\begin{array}{l}\text { Re-election } \\
\text { (dummy) }\end{array}$ & $\begin{array}{c}\text { Right- } \\
\text { wing } \\
\text { (dummy) }\end{array}$ & $\begin{array}{l}\text { Unem- } \\
\text { ployment } \\
\text { rate (log) }\end{array}$ & $\begin{array}{l}\text { Inflation } \\
\text { Rate (log) }\end{array}$ & $\begin{array}{c}\text { Govern- } \\
\text { ment } \\
\text { fractionali- } \\
\text { zation }\end{array}$ & $\begin{array}{c}\text { Public } \\
\text { Expenditures } \\
\text { in } \\
\text { GDP, term } \\
\text { average (log) }\end{array}$ & \begin{tabular}{|} 
Distortion in \\
Public \\
Expenditures, \\
percentual \\
points (log)
\end{tabular} & $\begin{array}{l}\% \text { People } \\
\text { with } \\
\text { secondary } \\
\text { education } \\
\text { (log) }\end{array}$ \\
\hline \multirow{5}{*}{$\begin{array}{l}\text { Grouped } \\
\text { Variables }\end{array}$} & Observations & 362 & 390 & 400 & 342 & 414 & 389 & 353 & 393 & 399 & 398 \\
\hline & Maximum & 3.912 & 35 & 1 & 1 & 4.021 & 3.045 & 1 & 4.228 & 0.379 & 2.996 \\
\hline & Minimum & -1.759 & 1 & 0 & 0 & 0.211 & -0.069 & 0.007 & 2.012 & -0.492 & 0.693 \\
\hline & Mean & -0.116 & 4.782 & 0.817 & 0.406 & 3.028 & 0.096 & 0.394 & 3.201 & -0.008 & 1.913 \\
\hline & Stand.Dev. & 0.678 & 5.23 & 0.387 & 0.492 & 1.313 & 0.191 & 0.218 & 0.437 & 0.089 & 0.617 \\
\hline \multirow{5}{*}{$\begin{array}{l}\text { Non Central } \\
\text { and Eastern } \\
\text { European } \\
\text { countries }\end{array}$} & Observations & 216 & 214 & 216 & 215 & 214 & 215 & 214 & 212 & 219 & 213 \\
\hline & Maximum & 1.078 & 15 & 1 & 1 & 3.998 & 0.693 & 1 & 3.989 & 0.371 & 2.833 \\
\hline & Minimum & -1.601 & 1 & 0 & 0 & 0.211 & -0.011 & 0.109 & 2.012 & -0.492 & 0.693 \\
\hline & Mean & -0.265 & 3.877 & 0.777 & 0.461 & 2.115 & 0.069 & 0.329 & 3.324 & -0.011 & 1.622 \\
\hline & Stand.Dev. & 0.497 & 2.701 & 0.417 & 0.499 & 1.112 & 0.092 & 0.121 & 0.404 & 0.075 & 0.542 \\
\hline \multirow{5}{*}{$\begin{array}{l}\text { Central and } \\
\text { Eastern } \\
\text { European } \\
\text { countries }\end{array}$} & Observations & 101 & 103 & 106 & 101 & 110 & 109 & 102 & 100 & 107 & 100 \\
\hline & Maximum & 3.912 & 35 & 1 & 1 & 4.021 & 3.045 & 1 & 4.228 & 0.379 & 2.996 \\
\hline & Minimum & -1.759 & 1 & 0 & 0 & 0.234 & -0.069 & 0.007 & 2.175 & -0.307 & 1.262 \\
\hline & Mean & 0.045 & 5.101 & 0.851 & 0.356 & 3.728 & 0.126 & 0.381 & 3.075 & -0.003 & 2.457 \\
\hline & Stand.Dev. & 0.803 & 5.121 & 0.357 & 0.479 & 1.471 & 0.258 & 0.189 & 0.434 & 0.101 & 0.294 \\
\hline
\end{tabular}


Table 2

Relationship between Win-margin and Public Expenditure Opportunism

\begin{tabular}{|c|c|c|c|}
\hline & All & All & All \\
\hline & $1960-2006^{\star}$ & 1960-2006* & $1960-2006^{*}$ \\
\hline & GMM 1 & 3SLS & FIML \\
\hline & Win-Margin & Win-Margin & Win-Margin \\
\hline Win-Margin (previous election) & $\begin{array}{l}0.578 a \\
(0.016)\end{array}$ & $\begin{array}{l}0.584 \mathrm{a} \\
(0.022)\end{array}$ & $\begin{array}{l}0.508 \mathrm{a} \\
(0.008)\end{array}$ \\
\hline years in incumbency & $\begin{array}{c}-0.015 \mathrm{a} \\
(0.002)\end{array}$ & $\begin{array}{l}-0.021 \mathrm{a} \\
(0.008)\end{array}$ & $\begin{array}{l}-0.007 \mathrm{a} \\
(0.001)\end{array}$ \\
\hline re-election & $\begin{array}{c}-0.200 \mathrm{a} \\
(0.018)\end{array}$ & $\begin{array}{c}-0.206 \mathrm{a} \\
(0.024)\end{array}$ & $\begin{array}{c}-0.192 \mathrm{a} \\
(0.010)\end{array}$ \\
\hline unemployment & $\begin{array}{c}-0.016 \text { a } \\
(0.002)\end{array}$ & $\begin{array}{c}-0.022 \mathrm{a} \\
(0.008)\end{array}$ & $\begin{array}{c}-0.011 a \\
(0.001)\end{array}$ \\
\hline inflation & $\begin{array}{c}-0.442 \mathrm{a} \\
(0.044)\end{array}$ & $\begin{array}{c}-0.448 \mathrm{a} \\
(0.050)\end{array}$ & $\begin{array}{c}-0.438 \mathrm{a} \\
(0.036)\end{array}$ \\
\hline government fractionalization & $\begin{array}{l}0.726 \mathrm{a} \\
(0.081)\end{array}$ & $\begin{array}{l}0.732 \mathrm{a} \\
(0.087)\end{array}$ & $\begin{array}{l}0.718 \mathrm{a} \\
(0.078)\end{array}$ \\
\hline distortion in expenditures & $\begin{array}{l}2.518 \mathrm{a} \\
(0.283)\end{array}$ & $\begin{array}{l}2.524 \mathrm{a} \\
(0.289)\end{array}$ & $\begin{array}{l}2.510 \mathrm{a} \\
(0.276)\end{array}$ \\
\hline Central and Eastern European & $\begin{array}{l}0.062 \mathrm{a} \\
(0.024)\end{array}$ & $\begin{array}{l}0.068 \mathrm{a} \\
(0.030)\end{array}$ & $\begin{array}{l}0.054 \mathrm{a} \\
(0.016)\end{array}$ \\
\hline Adjusted R2 & 0.532 & 0.591 & 0.481 \\
\hline N (observations) & 303 & 305 & 306 \\
\hline & $\begin{array}{l}\text { distortion in } \\
\text { expenditures }\end{array}$ & $\begin{array}{l}\text { distortion in } \\
\text { expenditures }\end{array}$ & $\begin{array}{l}\text { distortion in } \\
\text { expenditures }\end{array}$ \\
\hline win-margin & $\begin{array}{c}-0.036 \mathrm{a} \\
(0.005)\end{array}$ & $\begin{array}{c}-0.042 \mathrm{a} \\
(0.011)\end{array}$ & $\begin{array}{c}-0.030 \mathrm{a} \\
(0.001)\end{array}$ \\
\hline public expenditures & $\begin{array}{l}0.056 \mathrm{a} \\
(0.003)\end{array}$ & $\begin{array}{l}0.062 \mathrm{a} \\
(0.009)\end{array}$ & $\begin{array}{l}0.047 \mathrm{a} \\
(0.002)\end{array}$ \\
\hline re-election & $\begin{array}{l}-0.005 \\
(0.003)\end{array}$ & $\begin{array}{l}-0.011 \\
(0.009)\end{array}$ & $\begin{array}{l}-0.003 \\
(0.002)\end{array}$ \\
\hline right-wing & $\begin{array}{l}0.008 \mathrm{a} \\
(0.002)\end{array}$ & $\begin{array}{l}0.014 \mathrm{a} \\
(0.008)\end{array}$ & $\begin{array}{l}0.009 \mathrm{a} \\
(0.003)\end{array}$ \\
\hline $\begin{array}{l}\% \text { population with secondary } \\
\text { school }\end{array}$ & $\begin{array}{l}-0.005 \mathrm{a} \\
(0.001)\end{array}$ & $\begin{array}{l}-0.011 \mathrm{a} \\
(0.004)\end{array}$ & $\begin{array}{l}-0.006 \mathrm{a} \\
(0.001)\end{array}$ \\
\hline Central and Eastern European & $\begin{array}{l}0.023 \mathrm{a} \\
(0.004)\end{array}$ & $\begin{array}{l}0.029 \mathrm{a} \\
(0.006)\end{array}$ & $\begin{array}{l}0.019 a \\
(0.005)\end{array}$ \\
\hline Adjusted R2 & 0.307 & 0.365 & 0.385 \\
\hline $\mathbf{N}$ (observations) & 303 & 305 & 306 \\
\hline
\end{tabular}

Significance level: $1 \%$ (a); 5\% (b); 10\% (c)

Standard errors between parentheses

* election years

System of simultaneous equations estimated by the method at the top of the column.

Models estimated with a constant and with dummy variables for country and time specific effects. 
Table 3

Estimates in Our System of Simultaneous Equations - Central and Eastern European Countries

\begin{tabular}{|c|c|c|c|}
\hline & $\begin{array}{l}\text { Central-Eastern } \\
\text { European }\end{array}$ & $\begin{array}{l}\text { Central-Eastern } \\
\text { European }\end{array}$ & $\begin{array}{c}\text { Central-Eastern } \\
\text { European }\end{array}$ \\
\hline & $1960-2006^{\star}$ & $1960-2006^{\star}$ & $1960-2006^{\star}$ \\
\hline & GMM 1 & 3SLS & FIML \\
\hline & Win-Margin & Win-Margin & Win-Margin \\
\hline $\begin{array}{l}\text { Win-Margin (previous } \\
\text { election) }\end{array}$ & $\begin{array}{l}0.366 \mathrm{a} \\
(0.053)\end{array}$ & $\begin{array}{l}0.370 \mathrm{a} \\
(0.056)\end{array}$ & $\begin{array}{l}0.364 \mathrm{a} \\
(0.052)\end{array}$ \\
\hline years in incumbency & $\begin{array}{c}-0.014 \mathrm{~b} \\
(0.005)\end{array}$ & $\begin{array}{l}0.018 \mathrm{~b} \\
(0.007)\end{array}$ & $\begin{array}{c}-0.012 \mathrm{~b} \\
(0.002)\end{array}$ \\
\hline re-election & $\begin{array}{c}-1.074 \mathrm{a} \\
(0.151)\end{array}$ & $\begin{array}{c}-1.078 \mathrm{a} \\
(0.165)\end{array}$ & $\begin{array}{c}-1.072 \mathrm{a} \\
(0.149)\end{array}$ \\
\hline unemployment & $\begin{array}{c}-0.020 \mathrm{a} \\
(0.004)\end{array}$ & $\begin{array}{c}-0.024 \mathrm{a} \\
(0.008)\end{array}$ & $\begin{array}{c}-0.018 \mathrm{a} \\
(0.002)\end{array}$ \\
\hline inflation & $\begin{array}{c}-0.931 \mathrm{a} \\
(0.171)\end{array}$ & $\begin{array}{c}-0.935 \mathrm{a} \\
(0.175)\end{array}$ & $\begin{array}{c}-0.929 \mathrm{a} \\
(0.169)\end{array}$ \\
\hline government fractionalization & $\begin{array}{l}0.014 \mathrm{a} \\
(0.005)\end{array}$ & $\begin{array}{l}0.018 \mathrm{a} \\
(0.009)\end{array}$ & $\begin{array}{l}0.012 \mathrm{a} \\
(0.006)\end{array}$ \\
\hline distortion in expenditures & $\begin{array}{l}-0.207 \\
(0.592)\end{array}$ & $\begin{array}{l}-0.211 \\
(0.596)\end{array}$ & $\begin{array}{l}-0.201 \\
(0.589)\end{array}$ \\
\hline Adjusted R2 & 0.516 & 0.538 & 0.513 \\
\hline N (observations) & 52 & 55 & 53 \\
\hline & $\begin{array}{l}\text { distortion in } \\
\text { expenditures }\end{array}$ & $\begin{array}{l}\text { distortion in } \\
\text { expenditures }\end{array}$ & $\begin{array}{l}\text { distortion in } \\
\text { expenditures }\end{array}$ \\
\hline win-margin & $\begin{array}{l}-0.015 \\
(0.012)\end{array}$ & $\begin{array}{l}-0.019 \\
(0.016)\end{array}$ & $\begin{array}{l}-0.013 \\
(0.011)\end{array}$ \\
\hline nublio ornonditumo & $0.065 \mathrm{a}$ & $0.069 \mathrm{a}$ & $0.062 \mathrm{a}$ \\
\hline pubirc expenantures & $(0.010)$ & $(0.014)$ & $(0.008)$ \\
\hline re-election & $\begin{array}{c}-0.178 \mathrm{a} \\
(0.062)\end{array}$ & $\begin{array}{c}-0.182 \mathrm{a} \\
(0.066)\end{array}$ & $\begin{array}{c}-0.176 \mathrm{a} \\
(0.060)\end{array}$ \\
\hline right-wing & $\begin{array}{l}0.050 \mathrm{a} \\
(0.007)\end{array}$ & $\begin{array}{l}0.054 \mathrm{a} \\
(0.011)\end{array}$ & $\begin{array}{l}0.048 \mathrm{a} \\
(0.067)\end{array}$ \\
\hline $\begin{array}{l}\% \text { population with secondary } \\
\text { school }\end{array}$ & $\begin{array}{l}-0.003 \\
(0.003)\end{array}$ & $\begin{array}{l}-0.007 \\
(0.007)\end{array}$ & $\begin{array}{l}-0.001 \\
(0.001)\end{array}$ \\
\hline Adjusted R2 & 0.225 & 0.265 & 0.247 \\
\hline N (observations) & 52 & 55 & 53 \\
\hline
\end{tabular}

Significance level: $1 \%(a) ; 5 \%$ (b); $10 \%$ (c)

Standard errors between parentheses

* election years

System of simultaneous equations estimated by the method at the top of the column.

Models estimated with a constant and with dummy variables for country and time specific effects. 
Table 4

Estimates in Our System of Simultaneous Equations - the Rest of the Group

\begin{tabular}{|c|c|c|c|}
\hline & $\begin{array}{c}\text { Non Central-Eastern } \\
\text { European }\end{array}$ & $\begin{array}{c}\text { Non Central-Eastern } \\
\text { European }\end{array}$ & $\begin{array}{c}\text { Non Central-Eastern } \\
\text { European }\end{array}$ \\
\hline & $1960-2006^{*}$ & $1960-2006^{\star}$ & $1960-2006^{*}$ \\
\hline & GMM 1 & 3SLS & FIML \\
\hline & Win-Margin & Win-Margin & Win-Margin \\
\hline $\begin{array}{l}\text { Win-Margin (previous } \\
\text { election) }\end{array}$ & $\begin{array}{l}0.642 \mathrm{a} \\
(0.020)\end{array}$ & $\begin{array}{l}0.705 \mathrm{a} \\
(0.006)\end{array}$ & $\begin{array}{l}0.582 \mathrm{a} \\
(0.014)\end{array}$ \\
\hline years in incumbency & $\begin{array}{c}-0.016 \mathrm{a} \\
(0.002)\end{array}$ & $\begin{array}{l}-0.022 \mathrm{a} \\
(0.008)\end{array}$ & $\begin{array}{c}-0.010 a \\
(0.001)\end{array}$ \\
\hline re-election & $\begin{array}{c}-0.222 \mathrm{a} \\
(0.019)\end{array}$ & $\begin{array}{c}-0.228 \mathrm{a} \\
(0.026)\end{array}$ & $\begin{array}{l}-0.216 \mathrm{a} \\
(0.013)\end{array}$ \\
\hline unemployment & $\begin{array}{c}-0.022 \mathrm{a} \\
(0.002)\end{array}$ & $\begin{array}{c}-0.028 \mathrm{a} \\
(0.008)\end{array}$ & $\begin{array}{c}-0.028 \mathrm{a} \\
(0.001)\end{array}$ \\
\hline inflation & $\begin{array}{c}-0.615 a \\
(0.049)\end{array}$ & $\begin{array}{c}-0.621 \mathrm{a} \\
(0.055)\end{array}$ & $\begin{array}{c}-0.598 \mathrm{a} \\
(0.043)\end{array}$ \\
\hline $\begin{array}{l}\text { government } \\
\text { fractionalization }\end{array}$ & $\begin{array}{l}0.440 \mathrm{a} \\
(0.077)\end{array}$ & $\begin{array}{l}0.446 \mathrm{a} \\
(0.157)\end{array}$ & $\begin{array}{l}0.434 \mathrm{a} \\
(0.091)\end{array}$ \\
\hline distortion in expenditures & $\begin{array}{l}3.142 \mathrm{a} \\
(0.325)\end{array}$ & $\begin{array}{l}3.148 \mathrm{a} \\
(0.331)\end{array}$ & $\begin{array}{l}3.138 \mathrm{a} \\
(0.329)\end{array}$ \\
\hline Adjusted R2 & 0.393 & 0.387 & 0.424 \\
\hline \multirow[t]{2}{*}{ N (observations) } & 220 & 219 & 222 \\
\hline & $\begin{array}{c}\text { distortion in } \\
\text { expenditures }\end{array}$ & $\begin{array}{l}\text { distortion in } \\
\text { expenditures }\end{array}$ & $\begin{array}{c}\text { distortion in } \\
\text { expenditures }\end{array}$ \\
\hline win-margin & $\begin{array}{c}-0.053 \mathrm{a} \\
(0.005)\end{array}$ & $\begin{array}{c}-0.059 \mathrm{a} \\
(0.011)\end{array}$ & $\begin{array}{c}-0.047 a \\
(0.004)\end{array}$ \\
\hline public expenditures & $\begin{array}{l}0.055 \mathrm{a} \\
(0.003)\end{array}$ & $\begin{array}{l}0.061 \mathrm{a} \\
(0.009)\end{array}$ & $\begin{array}{l}0.049 \mathrm{a} \\
(0.003)\end{array}$ \\
\hline re-election & $\begin{array}{l}-0.006 \mathrm{c} \\
(0.003)\end{array}$ & $\begin{array}{l}-0.012 \mathrm{c} \\
(0.006)\end{array}$ & $\begin{array}{l}-0.006 \mathrm{c} \\
(0.003)\end{array}$ \\
\hline right-wing & $\begin{array}{c}0.002 \\
(0.603)\end{array}$ & $\begin{array}{c}0.008 \\
(0.609)\end{array}$ & $\begin{array}{c}0.001 \\
(0.609)\end{array}$ \\
\hline $\begin{array}{l}\text { \% population with } \\
\text { secondary school }\end{array}$ & $\begin{array}{c}-0.005 \mathrm{a} \\
(0.001)\end{array}$ & $\begin{array}{c}-0.019 \mathrm{a} \\
(0.002)\end{array}$ & $\begin{array}{c}-0.011 \mathrm{a} \\
(0.002)\end{array}$ \\
\hline Adjusted R2 & 0.239 & 0.218 & 0.249 \\
\hline N (observations) & 220 & 219 & 222 \\
\hline
\end{tabular}

Significance level: 1\% (a); 5\% (b); 10\% (c)

Standard errors between parentheses

* election years

System of simultaneous equations estimated by the method at the top of the column.

Models estimated with a constant and with dummy variables for country and time specific effects. 